\title{
Supercapacitor Based On a Commercially Prepared Hydroxyl Multiwalled Carbon Nanotubes With Hybrid Polymer Electrolyte
}

\author{
Lawal Sa'adu ${ }^{1}$, M. A. Hashim ${ }^{1} \&$ Karsono A. Dasuki ${ }^{1}$ \\ ${ }^{1}$ Faculty of Science and Technology, Universiti Sains Islam Malaysia (USIM), Malaysia \\ Correspondence: Lawal Sa'adu, Faculty of Science and Technology, Universiti Sains Islam Malaysia (USIM), \\ Malaysia. E-mail: lawals2004@gmail.com
}

Received: July 3, 2014 Accepted: July 28, 2014 Online Published: August 12, 2014

doi:10.5539/apr.v6n5p30 URL: http://dx.doi.org/10.5539/apr.v6n5p30

\begin{abstract}
This paper reports on the development of three pieces of supercapacitor cells for portable applications such as mobile and wearable energy storage. In a primary embodiment, the three developed supercapacitors cells, each, consist of two flexible electrodes fabricated on thin metal base substrates. The electrode, mainly a commercially prepared multiwalled hydroxyl carbon nanotubes (CPHMWCNTs), sandwich a hybrid solid polymeric separator doped with an appropriate ionic material acting as an electrolyte. The integrated separator and electrolyte layer was made of filter paper, a polyvinyl alcohol (PVA) doped with phosphoric acid at three different concentrations. The Three cells were then assembled and leveled as cell-A (C90PVdF-HFP10 |H50| C90PVdF-HFP10), cell-B (C90PVdF-HFP10 |H60| C90PVdF-HFP10) and cell-C (C90PVdF-HFP10 |H70| C90PVdF-HFP10). The evaluations of these three different electrodes and their substrate materials allowed for selection of a combination of active material and suitable percentage concentrations that yielded optimal supercapacitor performance. From the overall results of the electrochemical analysis of cyclic voltammetry $(\mathrm{CV})$, cell-B delivered higher capacitance of $86.60 .10 \mathrm{Fg}^{-1}$ which was higher than the capacitance obtained by cell-C $\left(65 \mathrm{Fg}^{-1}\right)$ and even doubling the capacitance obtained by cell-A $\left(42.1 \mathrm{Fg}^{-1}\right)$. Whereas the charge-discharge (CD) tests carried out in the cells reveals that, even at the lower voltage window of $1.5 \mathrm{~V}$, cell-B delivered better than cells $\mathrm{A}$ and $\mathrm{C}$ with a balanced and better discharge capacitance of $119.0 \mathrm{Fg}^{-1}$ and higher energy/power densities of $597.0 \mathrm{Jg}^{-1} / 12.6 \mathrm{Jg}^{-1} \mathrm{~s}^{-1}$ and very low internal resistance.
\end{abstract}

Keywords: supercapacitor, hydroxyl multiwalled carbon nanotubes, Differential Scanning Calorimetry (DSC) Analysis, cyclic voltammetry (CV), charge-discharge (CD), hybrid solid polymer electrolyte (HSPE)

\section{Introduction}

In every country across the globe, energy has become an issue of national security, especially with the current rise in the global economy (Dubal et al., 2013), the exhaustion of fossil fuels and increasing environmental pollution. Meeting the energy demands in an environmentally sustainable manner is currently the most important technological challenge facing the society. Energy storage devices can efficiently store electricity generated from renewable sources, such as solar, water, wind, thermoelectric, fuel cells, for reuse at many different scales. Therefore, energy storage devices, such as batteries and supercapacitors, have become a key to society (Shi et al., 2013).

Supercapacitor also known as Electrochemical Capacitor (EC) or ultracapacitor (Hashim et al., 2014; Inagaki et al.(a), 2014; Hashim \& Khiar, 2011; Burke, 2009) affords new, eco-friendly and low-cost energy storage device for progressive civilization and growing ecological agencies (Dubal et al., 2014), their characteristics comprising a combination of high power density (Wu et al., 2013) and a balanced or reasonable energy density (Dubal et al., 2013) with fast response time and almost infinite life cycleability (Zhao et al., 2011) can complement other storage devices such as batteries, conventional capacitors and fuel cells. Hence, the above properties make them suitable for use in many applications ranging from applications related to portable electronic devices (Perera et al., 2013) UPS, to a hybrid motor vehicles (Inagaki et al.(b), 2014; Qian et al., 2013).

In Electrochemical Double Layer Capacitors (EDLCs), the charge is stored electrostatically at the electrodeelectrolyte interface, so, as a result of this storage mechanism, these devices can be charged and discharged within a blink of seconds (Bockenfeld et al., 2013; Gund et al., 2013; Jiang et al., 2013). Electrodes based on carbon nanotubes (CNTs) deliver an impressive power and energy due to their high surface area, high conductivity and 
consequently, when functionalized, these electrodes, can deliver up to an optimum level of power and energy densities (Jiang et al., 2013). Hence, this study focused on the fabrication of supercapacitor based on commercially prepared hydroxyl multiwalled carbon nanotubes (CPHMWCNTs). Functionalized supercapacitors are believed to have some key features due to the functionalization processes that occurs in the CNTs chain. The widening of the pore sizes of the CNTs (when functionalized) will result in their improvement for the electrolyte infiltration and ion diffusion throughout the electrode. Other features include the wettability, excellent capacitance, and good charge-storage properties (Van Hooijdonk et al., 2013). Stability for long term storage is one of the merits of the functionalized CNTs (Capek, 2009).

\section{Methodology}

\subsection{Electrolytic Materials}

Three different polymer electrolytes which also served as the separators were prepared as follows; $\mathrm{The}_{3} \mathrm{HO}_{4}$ ( $>85 \mathrm{wt} . \%$ in water, molar mass of $98.00 \mathrm{gmol}^{-1}$, product, number of 1502-80) was obtained in aqueous form from R \& M marketing, Essex, UK brand, while the PVA (molecular weight; 89,000-98,000, $99+\%$ hydrolyzed) was obtained from Sigma Aldrich. Both $\mathrm{H}_{3} \mathrm{PO}_{4}$ and PVA were used as-received without further treatment or purification. An aqueous solution of PVA was then prepared by combining PVA with distilled water in the ratio of $1: 10$ by volume. This solution is mechanically agitated by magnetic stirring at $60^{\circ} \mathrm{C}$ for five hours to thoroughly dissolve the PVA in the distilled water. $\mathrm{H}_{3} \mathrm{PO}_{4}$ was then mixed with the PVA aqueous solution in the ratio of 70:30, 60:40 and 50:50 wt. \%.

These percentage weights were shown to have promising conductivities even at an ambient temperature. We have reported this development in (Hashim et al., 2012) for a hybrid electrolyte at a combination of 70:30 wt. \%. After the mixture cools to a room temperature, the resulting homogenous solution of $\mathrm{PVA} / \mathrm{H}_{3} \mathrm{PO}_{4}$ was cast over a plastic Petri dish. This was done after a cellulose filter paper (Whatman brand) was cut into a $6 \mathrm{~cm} \times 5.5 \mathrm{~cm}$ (sizes that fits into the Petri dish) and soaked into each of the aforementioned solutions. The above mixture took roughly four weeks before it dries. Thereafter, the resulting flexible hybrid solid polymer electrolyte (HSPE) that is peeled off from the Petri dish was used as the separator.

\subsection{Electrode Materials and Cell Assembly}

The Hydroxyl MWCNTs with the following specifications; -OH content of $0.71 \mathrm{wt} . \%$, an outer diameter of $>50$ $\mathrm{nm}$, length of 10-20 $\mu \mathrm{m}$, purity and Ash are both $>95 \mathrm{wt} . \%$, and $<1.5 \mathrm{wt} . \%$, respectively, Surface area of $>40 \mathrm{~m}^{2} \mathrm{~g}^{-1}$ and Conductivity of $>10^{2} \mathrm{Scm}^{-1}$ was purchased locally in Malaysia (with material code MH8 11/202). The binder used was $\mathrm{P}(\mathrm{VdF}-\mathrm{HFP})$ (average molecular weight of $\sim 400,000$; Mn of $\sim 130,000$ pellets; product number of 427160) was purchased from Sigma Aldrich. P(VdF-HFP) copolymer was found to meet all the requirements for use as a binder or even a polymer host in supercapacitor fabrication due to its electrochemical stability and performance, processability, and safety. Again, this co-polymer contains amorphous domains (HFP) which is capable of trapping large amounts of liquid electrolytes, and crystalline regions (VdF) which provide chemical stability and sufficient mechanical integrity for the processing (Lim et al., 2012). Moreover, P(VdF-HFP) is proven to have strong electron withdrawing, unique arrangement and high dielectric constant (Kim et al., 2013).

Therefore, the double layer capacitor was made with a mixture of $90 \mathrm{wt}$. \% of the CPHMWCNTs and $10 \mathrm{wt} . \%$ of $\mathrm{P}(\mathrm{VdF}-\mathrm{HFP})$, mixed inside a $20 \mathrm{ml}$ of the acetone. The slurry was then cast onto to the Aluminum foil and allowed to dry for about two hours at room temperature. Prior to that, an applicator was used to polish the slurry with the view to leveling it and obtaining a desired thickness which was around $0.127 \mathrm{~mm}$. The dried sample was then further dried in an oven for about 12 hours at a temperature of $100{ }^{\circ} \mathrm{C}$. Afterward, the solid films were obtained and were further cut into $2 \mathrm{~cm}^{2} \times 3 \mathrm{~cm}^{2}$ each. The weights of the films were measured by means of a micro-balance (Santorius, Ax 224) with an accuracy of $0.001 \mathrm{mg}$. The average weights of two electrode films that make a cell was around $0.224 \mathrm{~g}$. Using a Perspex of about $5 \mathrm{~cm} \mathrm{x} 4 \mathrm{~cm}$, the cell was set up by sandwiching two electrodes with the electrolyte and assembled in an innovative supercapacitor tester.

XRD spectra were obtained with an XRD (Philip X'Pert XRD with $\mathrm{Cu} \mathrm{K}_{\alpha}$ radiation of wavelength $\lambda=1.54056 \AA$ for $2 \boldsymbol{\theta}$ angles between $10^{\circ}$ and $\left.80^{\circ}\right)$ that used $\mathrm{Cu} \mathrm{K} \alpha$ radiation $(\lambda=1.5406 \AA)$ operating at $40 \mathrm{kV}$ and $30 \mathrm{~mA}$. The surface morphologies of all firms were investigated via FESEM (SU 8030 a family member of SU 8000; Resolution capability of $1.0 \mathrm{~nm} / 15 \mathrm{kV}, 1.3 \mathrm{~nm} / 1 \mathrm{kV}$ and abling magnification of $80 \mathrm{x}$ to $2,000,000 \mathrm{x}$ ). Charge-discharge (CD) and cyclic voltammetry (CV) analysis were respectively carried out using a newer battery charger which has been interfaced to a computer called "e-machines" (model: ET1850, Rating: 100-127/220-240Vac, 6/3.15 A (6/3, 15 A), 60/50 Hz) and Gamry instrument Framework (version 5.61). The following symmetric capacitor cells were assembled; 


\section{Cells: Cell A - H90PVDF-HFP10 | H50 | H90PVDF-HFP10 \\ Cell B - H90PVDF-HFP10 | H60 | H90PVDF-HFP10 \\ Cell C - H90PVDF-HFP10 | H70 | H90PVDF-HFP10}

\section{Results and Discussions}

\subsection{Microstructure Characterizations}

In order to examine the microstructure of the samples in this work, XRD, and FESEM were used. The spectra of the X-ray in these samples were obtained from an XRD; a Philip X'Pert XR) model with $\mathrm{Cu} \mathrm{K}_{\alpha}$ radiation of wavelength $\lambda=1.54056 \AA$ for $2 \theta$ angles between $10^{\circ}$ and $80^{\circ}$ that used $\mathrm{Cu} \mathrm{K} \alpha$ radiation $(\lambda=1.5406 \AA)$ operating at $40 \mathrm{kV}$ and $30 \mathrm{~mA}$. The XRD analysis of the H90PVdF-HFP10 electrode is depicted in Figure 1. As seen from this figure, all diffraction peaks can be observed and the major diffraction peaks of the CPHMWCNTs can also be seen clearly. The first two peaks that appeared at in $2 \theta=26^{\circ}$ and $\theta=43^{\circ}$ which matched with (002) and (101) respectively indicate the presence of the embedded graphite CNT, while the last peak on the right side at $2 \theta=56.1^{0}$ might also be considered as part of the CNT. Thus, the intensity of the peak observed, could correspond to the high concentration of the as-prepared carbon electrode conductivity (Dong et al., 2007). Furthermore, at the left hand side of the trace, there appeared a diffraction peak at $2 \theta=20.1^{0}$ which correspond to the crystalline peaks of the PVDF (Stolarska et al., 2007). Similar XRD results were obtained by (Li et al., 2010).

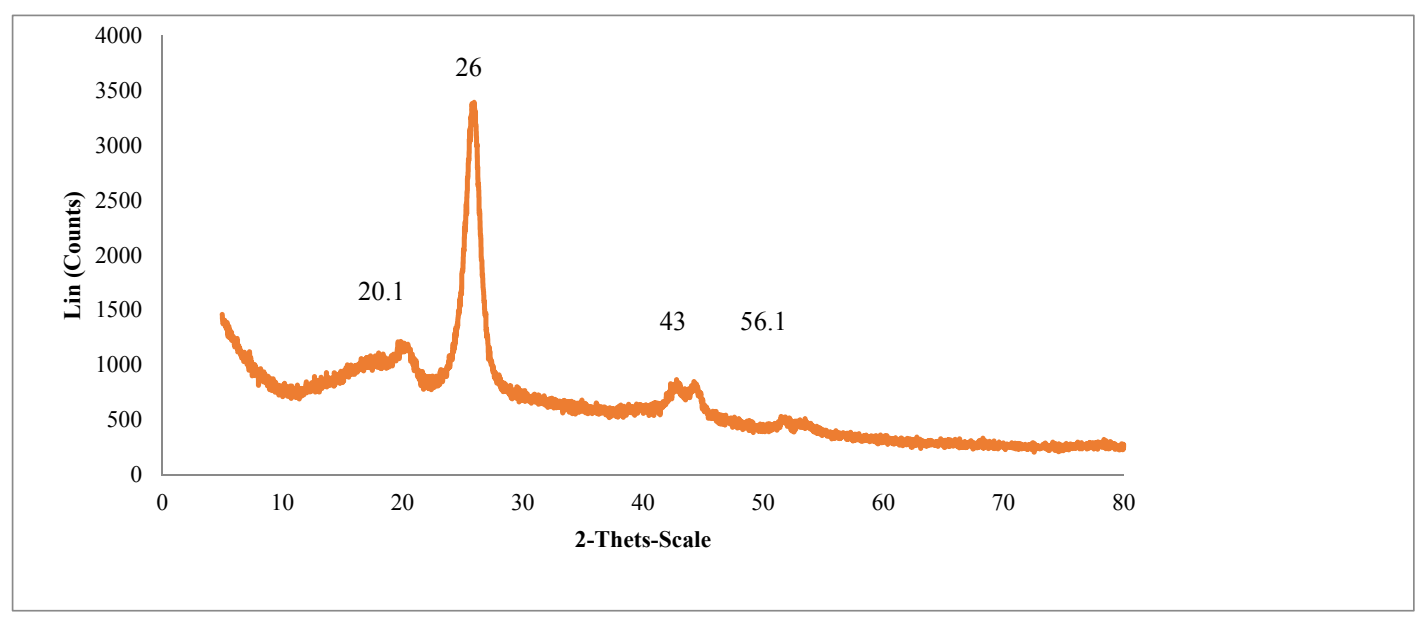

Figure 1. XRD Analysis of CPHMWCNTs

FESEM images for the as-prepared electrode and the HSPE are shown in the Figures 2-7. The morphological structure is necessary for the required electrochemical performance of the cell in order to facilitate the electrolyte penetration and ion diffusion in the electrode. Thus, Figure 2, depicts the FESEM images of sample electrode with $90 \%$ of the CPHMWCNTs. This sample exhibits similar regular, entangled and smooth surface morphology with the outer diameter of $\sim 28 \mathrm{~nm}$ and lengths of several micrometers. Although, few larger tubes are cited in the FESEM structure, this indicates that, the original MWCNT has been functionalized, since the normal sizes does not exceed $50 \mathrm{~nm}$. Detail structures can be seen more clearly in Figure 3, where the FESEM images of CPHMWCNTs were taken at different magnifications of (a); $3.6 \mathrm{~mm}$ x $50 \mathrm{k}(1 \mu \mathrm{m})(\mathrm{b}) ; 3.6 \mathrm{~mm} \times 100 \mathrm{k}(500 \mathrm{~nm})$ and (c); $3.6 \mathrm{~mm} \times 150 \mathrm{k}(300 \mathrm{~nm})$. However, in Figure 4 the FESEM images of HSPE containing $50 \mathrm{wt}$ \% of both PVA and $\mathrm{H}_{3} \mathrm{PO}_{4}$ at a magnification of (a); $3.5 \mathrm{~mm} \times 35 \mathrm{LM}(1.00 \mathrm{~mm})(\mathrm{b}) ; 3.5 \mathrm{~mm} \times 150 \mathrm{LM}(300 \mu \mathrm{m})$ and (c) $3.5 \mathrm{~mm} \times 300 \mathrm{LM}(100 \mu \mathrm{m})$ were all shown. Displayed in the images is the entangling nature of the surface of the sample which was due to the incorporation of the filter paper. Except in a few spots, all over the surface of the polymer looks unique as the Watman filter paper was coated with composites of both $\mathrm{PVA}$ and $\mathrm{H}_{3} \mathrm{PO}_{4}$.

The same is applicable to Figure 5. Whereas, Figure 6, depicts FESEM images of HSPE with the content of 70 wt. \% of $\mathrm{H}_{3} \mathrm{PO}_{4}, 30$ wt. \% of PVA and at a magnification of (a); $3.5 \mathrm{~mm} \times 35 \mathrm{LM}(1.00 \mathrm{~mm})(\mathrm{b}) ; 3.5 \mathrm{~mm} \times 150 \mathrm{LM}$ $(300 \mu \mathrm{m})$ and (c) $3.5 \mathrm{~mm} \times 300 \mathrm{LM}(100 \mu \mathrm{m})$. There are some obvious changes in the surface morphology. Several places spotted seem to have openings almost everywhere, which indicates few flaws in the coating which may 
result in lower capacitance. Moreover, Figure 7 depicts the FESEM images of C90PVdF-HFP10 electrode overlapped on HSPE containing $60 \mathrm{wt}$. \% of the $\mathrm{H}_{3} \mathrm{PO}_{4}$ and $40 \mathrm{wt}$. \% of PVA at the magnifications of $\mathrm{x} 45 \mathrm{k}(1.00$ $\mu \mathrm{m})$. This image was also taken at an angle of $30^{\circ}$ in order to examine the edge contact at the electrode and electrolyte and to deduce the required thickness needed during the sandwiching of the electrolytes between the electrolytes to avoid high resistance.

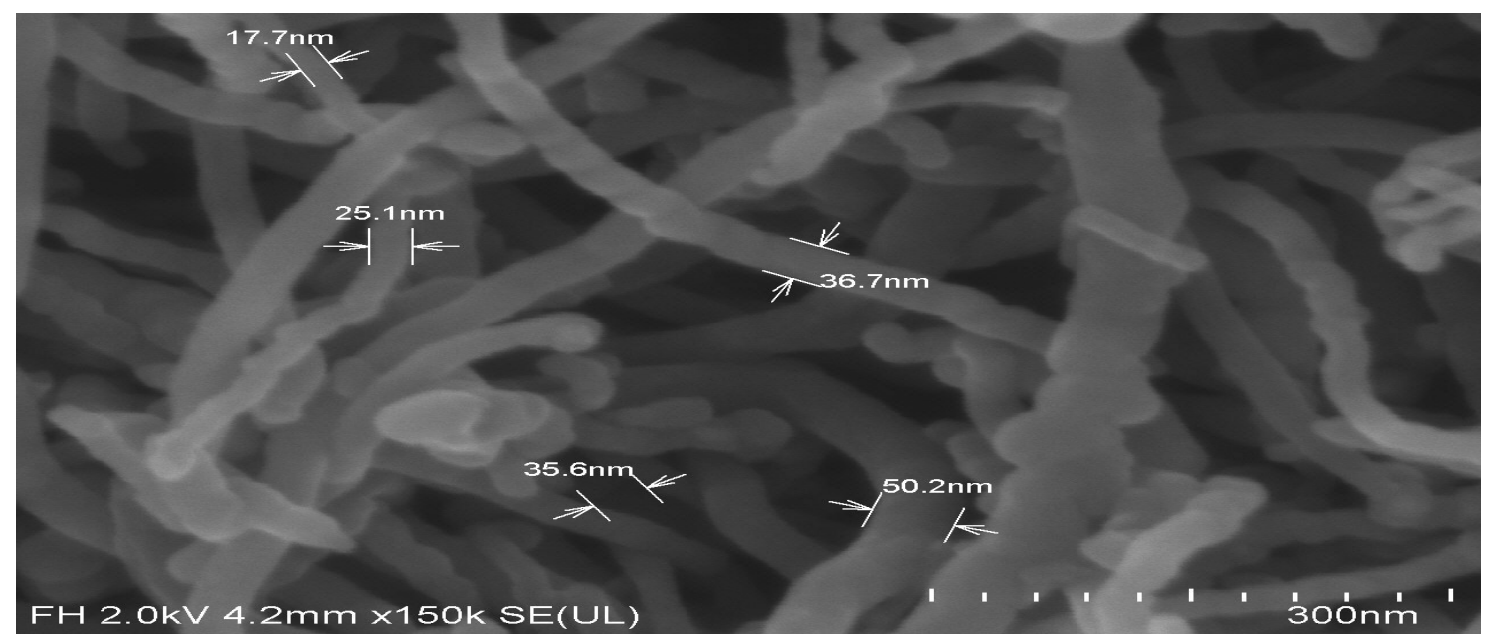

Figure 2. FESEM images of sample with $90 \%$ CPHMWNTs showing average diameters of the pore sizes at the magnifications of $4.2 \mathrm{~mm} \times 150 \mathrm{k}$
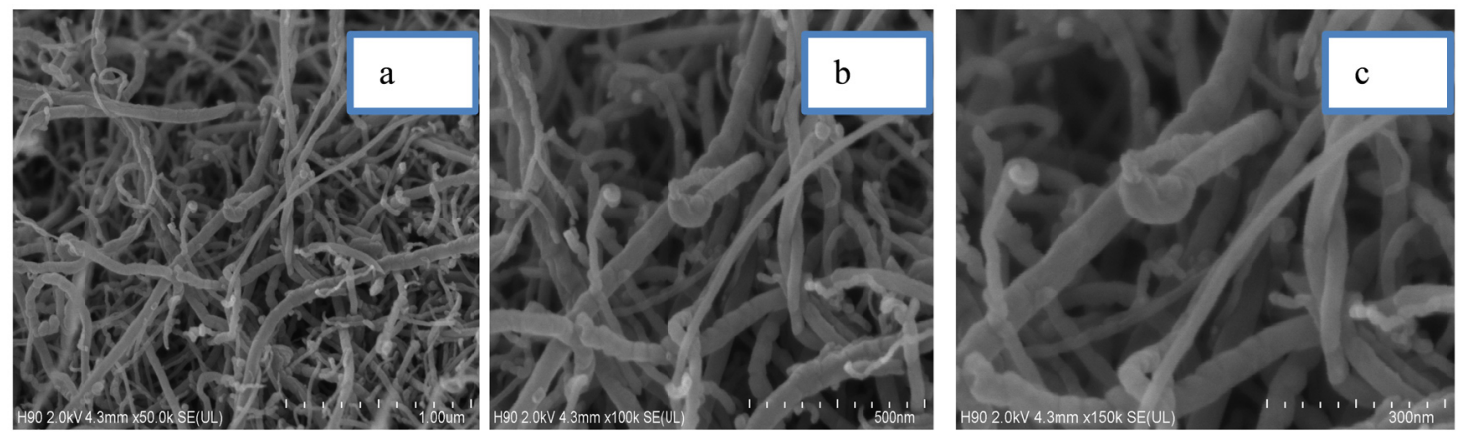

Figure 3. FESEM images of CPHMWCNTs showing H90PVdF-HFP10 electrode at a magnifications of (a); 3.6 $\mathrm{mm} \times 50 \mathrm{k}(1 \mu \mathrm{m})(\mathbf{b}) ; 3.6 \mathrm{~mm} \times 100 \mathrm{k}(500 \mathrm{~nm})$ and (c); $3.6 \mathrm{~mm} \times 150 \mathrm{k}(300 \mathrm{~nm})$
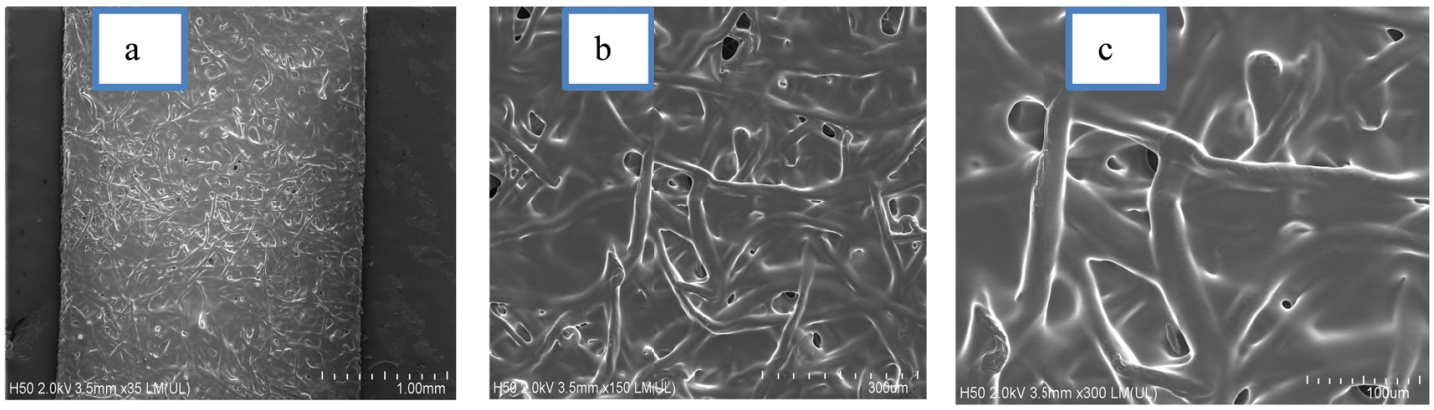

Figure 4. FESEM images of HSPE containing $50 \mathrm{wt}$ \% of both PVA and $\mathrm{H}_{3} \mathrm{PO}_{4}$ at a magnification of (a); $3.5 \mathrm{~mm}$ x $35 \mathrm{LM}(1.00 \mathrm{~mm})(\mathbf{b}) ; 3.5 \mathrm{~mm} \times 150 \mathrm{LM}(300 \mu \mathrm{m})$ and (c); $3.5 \mathrm{~mm} \times 300 \mathrm{LM}(100 \mu \mathrm{m})$ 

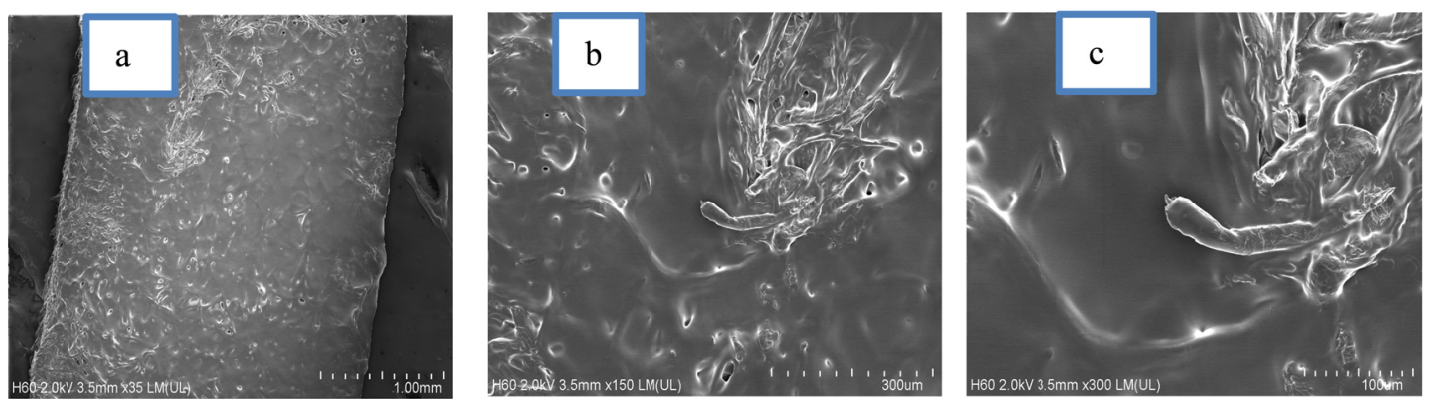

Figure 5. FESEM images of $\mathrm{HSPE}$ containing 60 wt. \% of $\mathrm{H}_{3} \mathrm{PO}_{4}, 40$ wt. \% of PVA at a magnification of (a); 3.5 $\mathrm{mm} \times 35 \mathrm{LM}(1.00 \mathrm{~mm})(\mathbf{b}) ; 3.5 \mathrm{~mm} \times 150 \mathrm{LM}(300 \mu \mathrm{m})$ and $(\mathbf{c}) ; 3.5 \mathrm{~mm} \times 300 \mathrm{LM}(100 \mu \mathrm{m})$.
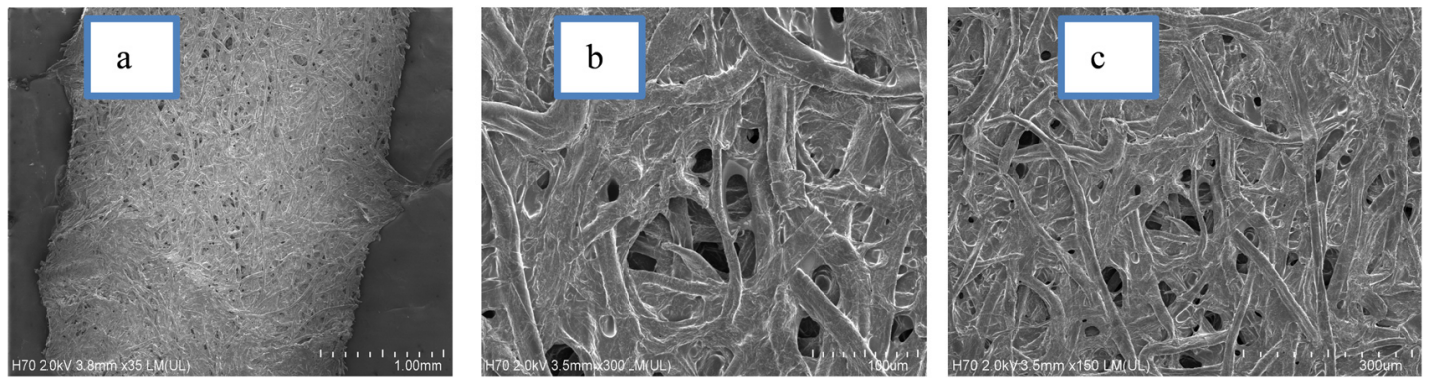

Figure 6. FESEM images of HSPE containing 70 wt. $\%$ of $\mathrm{H}_{3} \mathrm{PO}_{4}, 30$ wt. \% of PVA at a magnification of (a); 3.5 $\mathrm{mm} \times 35 \mathrm{LM}(1.00 \mathrm{~mm})(\mathbf{b}) ; 3.5 \mathrm{~mm} \times 150 \mathrm{LM}(300 \mu \mathrm{m})$ and $(\mathbf{c}) ; 3.5 \mathrm{~mm} \times 300 \mathrm{LM}(100 \mu \mathrm{m})$.

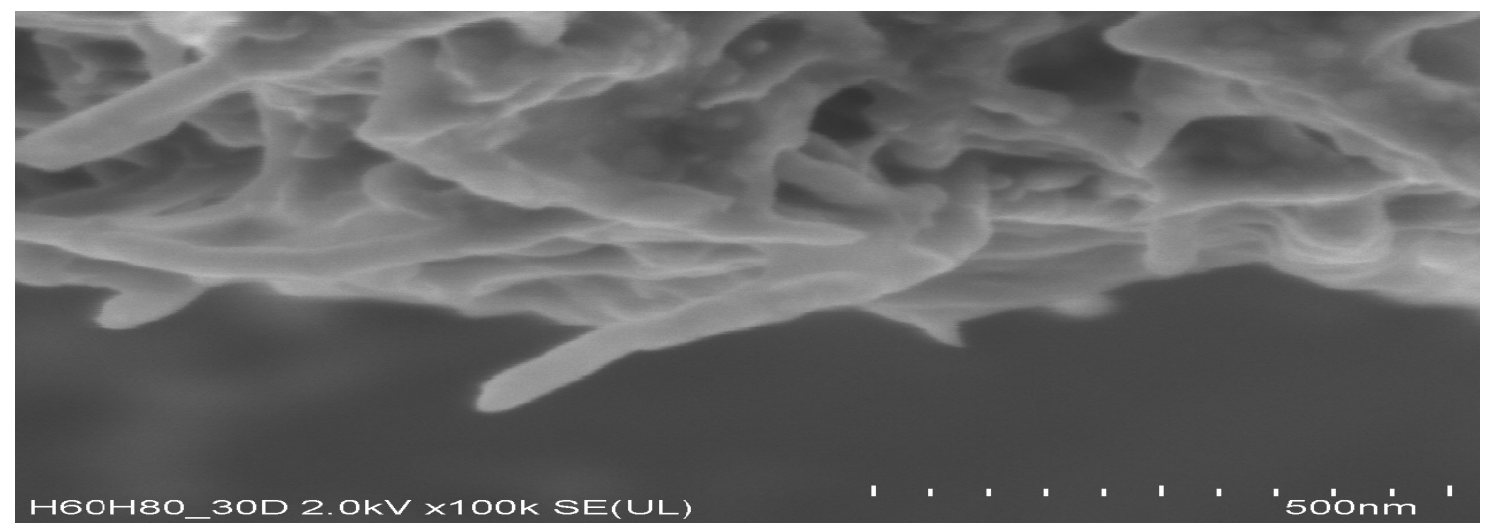

Figure 7. FESEM images of H90PVdF-HFP10 electrode overlapped on HSPE containing $60 \mathrm{wt} . \% \mathrm{of}_{3} \mathrm{PO}_{4}$ and $40 \mathrm{wt} . \%$ of PVA at the magnifications of $\mathrm{x} 100 \mathrm{k}(500 \mathrm{~nm})$ and an angle of $30^{\circ}$

\subsection{Thermogravimetric Analysis (TGA)}

The analysis of the temperature stability of the sample was investigated by thermal analyzer in the scale-range of $50{ }^{\circ} \mathrm{C}$ to $1000{ }^{\circ} \mathrm{C}$ under nitrogen gas $\left(\mathrm{N}_{2}\right)$ flow at a heating rate of $10{ }^{\circ} \mathrm{C} \mathrm{min}^{-1}$ on a METTLER, STAR ${ }^{\mathrm{e}} \mathrm{SW} 10.00$. We have used similar techniques in our previous work (Hashim et al., 2014). The thermal stability of the samples was discerned in Figure 8. The Figures were (a); $0 \%$ sample (Background) (b); pure CPHMWCNTs (c) H90PVdF-HFP10 - Single scale (d); H90PVdF-HFP10 - Double scale.

At the starting, we analyzed background heating, in order to clear any ruminant residue and to enable the re-calibration of the analyzer. From the traces in Figure 8 (b) it can be observed that, the pure CPHMWCNTs has the major loss of just $10.0522 \%$ occurring at $696.58^{\circ} \mathrm{C}$ leaving a residue of $88.7270 \%$. Basically, this results show that pure MWCNTs have very good thermal stability and consequently, good in application of electrochemical devices. While in Figure 8 (b and c), it can notice that, when the active material (i.e. the binder) was added into a single electrode, three losses were recorded. The initial loss of $0.9300 \%$ of the total samples occurs at $274.66{ }^{\circ} \mathrm{C}$, 
then the second loss of $4.0847 \%$ occurred at $388.95{ }^{\circ} \mathrm{C}$ and the highest loss of $7.1 \%$ was noticed at $605.36{ }^{\circ} \mathrm{C}$. This shows that incorporating a binder (of negligible quantity) into the pure CPHMWCNTs does not affect the conductivity supercapacitor.
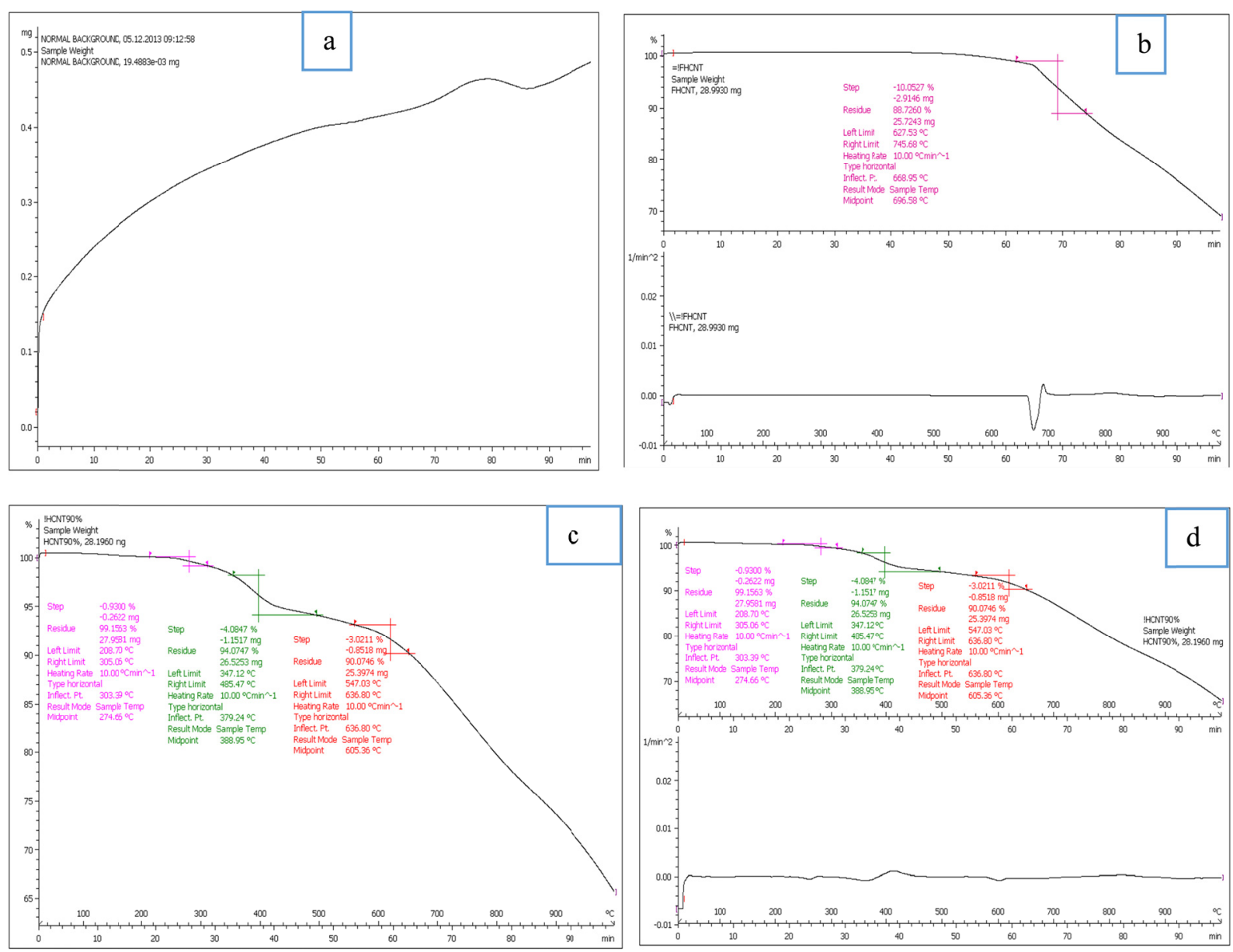

Figure 8. TGA of the electrode at (a); $0 \%$ sample (Background) (b); pure CPHWMCNT (c); H90PVdF-HFP10 Single scale (d); H90PVdF-HFP10 - Double scale

\subsection{Electrochemical Behavior}

The electrochemical behaviors of CPHMWCNTs were investigated by the CV and CD measurements. CV measurement was firstly performed to evaluate the electrochemical potential window and adequately quantify the specific capacitance of the electrodes in these cells using two-electrode system. Figure 9 reveals the CV of Cell -A (H90PVdF-HFP10 |H50| H90PVdF-HFP10) at (a); scan rates of 10, 50 and $100 \mathrm{mV}$, within a potential window of $0.0-3.0 \mathrm{~V}$ and (b); scan rate of $50 \mathrm{mV}$; within a potential window of $0.0-1.0 \mathrm{~V}$. From the resulting $\mathrm{CV}$ curves, it can be discerned that, the $\mathrm{CV}$ of the cell at a scan rate of $50 \mathrm{mV}$ and $1 \mathrm{~V}$ - voltage shows a rectangular shape and mirror-symmetric, indicating an ideal supercapacitive behavior for CPHMWCNTs. We then calculated the specific capacitance of the electrode materials obtained in the two-electrode system by integrating the $\mathrm{CV}$ curves in that Figure. However, the CV curves are rather in leaf-like symmetric in shape, when the voltage was extended to $3.0 \mathrm{~V}$, indicating a closely ideal capacitive behavior. The specific capacitance was obtained to be $42.0 \mathrm{Fg}^{-1}, 15.0 \mathrm{Fg}^{-1}$, and $11.1 \mathrm{Fg}^{-1}$ for the scan rates of 10,50 and $100 \mathrm{mV}$, respectively. These results prove that there is a strong correlation between capacitance value and the scan rate. The decrease in specific capacitance of $42.0 \mathrm{Fg}^{-1}$ to $11.1 \mathrm{Fg}^{-1}$ could either be attributed to the slow transfer of ions on the electrode electrolyte interface (Shu et al., 2013) or due to the un-uniformity of the coated filter paper by the electrolyte as vindicated in the FESEM analysis, it also suggests an improved performance of supercapacitor at the decreasing scan rates. Noting from the $\mathrm{CV}$ from the cell at the scan rate of $50 \mathrm{mV}$ above, the potential window is quite stable for this electrode, 
we can, as a consequence, envision that, an operating cell with $1.5 \mathrm{~V}$ can be more stable especially when assembled in a three-electrode system.

Furthermore, Figure 10 also shows CV of Cell-B (H90PVdF-HFP10|H60| H90PVdF-HFP10) at various scan rates of (a); 10, 50 and $100 \mathrm{mV} ; 3 \mathrm{~V}$ - voltage window, and (b); $50 \mathrm{mV} ; 1 \mathrm{~V}$ - voltage window. The specific capacitances obtained in this cell were $88.6 \mathrm{Fg}^{-1}, 32.6 \mathrm{Fg}^{-1}$ and $22.7 \mathrm{Fg}^{-1}$ for scan rates of 10,50 and $100 \mathrm{mV}$ respectively. These results almost double that of cell-A which might be attributed to the increase in ionic conductivity in the polymer electrolyte of the HSPE. While Figure 11 depicts a CV of Cell $-\mathrm{C}$ (H90PVdF-HFP10 H70| H90PVdF-HFP10) at (a); scan rates of 1, 50 and $100 \mathrm{mV}, 3 \mathrm{~V}$ - voltage window, and (b); scan rate of $50 \mathrm{mV}, 1 \mathrm{~V}-$ voltage window. These $\mathrm{CV}$ curves result in a balance and modest capacitance value and is considered better of compare to the capacitance of cells A. The capacitance recorded here are $65.0 \mathrm{Fg}^{-1}, 36.6 \mathrm{Fg}^{-1}$ and $29.3 \mathrm{Fg}^{-1}$ for scan rates of 10,50 and $100 \mathrm{mV}$ respectively. Table 1 gave a summary results of the capacitance obtained in all the three cells. Figure 12 (a) summarizes the capacitance performance in the combined graph of capacitance against the scan rates for cells $\mathrm{A}, \mathrm{B}$

One important criterion in supercapacitor's fabrication and application is its ability to have long -term cycling stability. In this respect, the cycling endurance measurement over 5000 cycles for all the cells (as shown in Figure 12 (b)) was conducted using the CD test at the working voltage of $1.5 \mathrm{~V}$. This figure shows the resulting capacitance retention as a function of cycling number. It can be seen that of all the three cells, only cell-B (H90PVdF-HFP10 |H60| H90PVdF-HFP10) exhibits the best cycling stability with about $68 \%$ capacitance of its initial value after 5000 cycles.

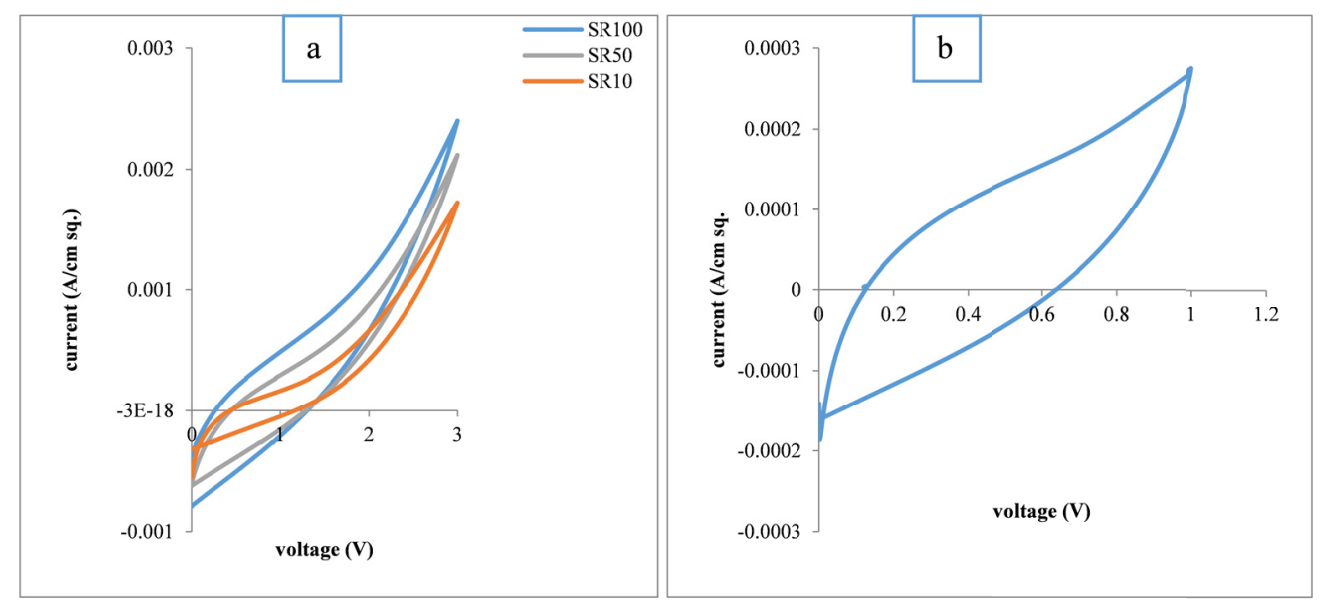

Figure 9. CV of Cell -A (H90PVdF-HFP10 |H50| H90PVdF-HFP10 at (a); scan rates of 1, 50 and $100 \mathrm{mV}, 3 \mathrm{~V}$ voltage window (b); scan rate of $50 \mathrm{mV} ; 1 \mathrm{~V}$ - voltage window

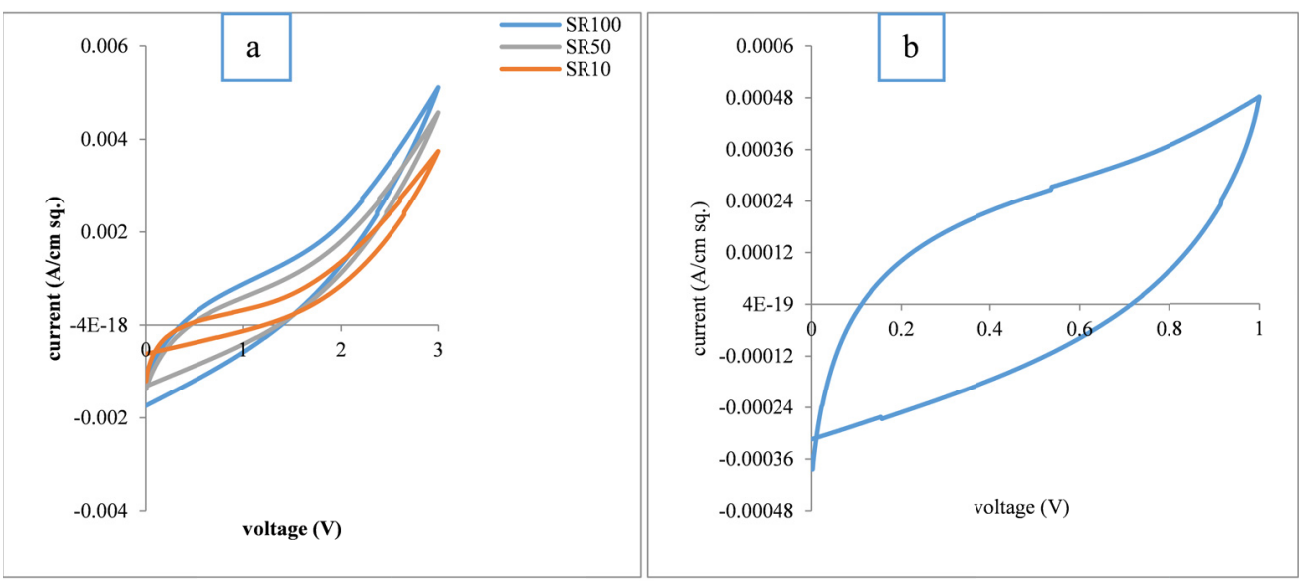

Figure 10. CV of Cell -A (H90PVdF-HFP10 |H60| H90PVdF-HFP10 at (a); scan rates of 1, 50 and $100 \mathrm{mV}, 3 \mathrm{~V}-$ voltage window (b); scan rate of $50 \mathrm{mV} ; 1 \mathrm{~V}$ - voltage window 


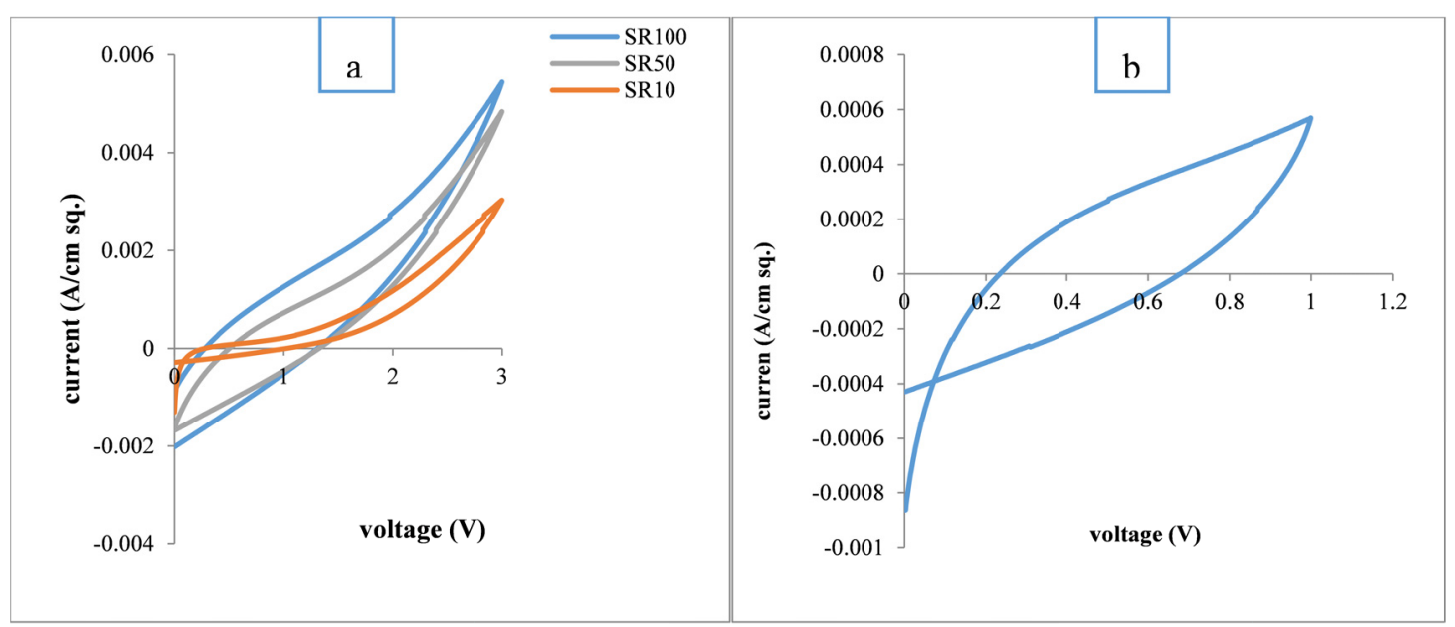

Figure 11. CV of Cell -A (H90PVdF-HFP10 |H70| H90PVdF-HFP10 at (a); scan rates of 1, 50 and $100 \mathrm{mV}, 3 \mathrm{~V}$ voltage window (b); scan rate of $50 \mathrm{mV} ; 1 \mathrm{~V}$ - voltage window

Table 1. Performance of Supercapacitor by the CV

\begin{tabular}{lcccc}
\hline \multirow{2}{*}{ Cells } & Working voltage & \multicolumn{3}{c}{ Capacitance value of different scan rates $\left(\mathrm{Fg}^{-1}\right)$} \\
\cline { 3 - 5 } & $(\mathrm{V})$ & $100 \mathrm{mV}$ & $50 \mathrm{mV}$ & $10 \mathrm{mV}$ \\
\hline A-H90H50 & 3 & 11.1 & 15.0 & 42.1 \\
B-H90H60 & 3 & 22.7 & 32.6 & 86.6 \\
C-H90H70 & 3 & 29.3 & 36.6 & 65.0 \\
\hline
\end{tabular}

Table 2. Performance of Supercapacitor by the CD

\begin{tabular}{cccccc}
\hline Cells & $\begin{array}{c}\text { Working } \\
\text { voltage } \\
(\mathrm{V})\end{array}$ & $\begin{array}{c}\mathrm{C}_{\mathrm{d}} \\
\left(\mathrm{Fg}^{-1}\right)\end{array}$ & $\begin{array}{c}\mathrm{ESR} \\
\left(\Omega \mathrm{cm}^{2}\right)\end{array}$ & $\begin{array}{c}\text { Energy } \\
\text { density } \\
\left(\mathrm{Jg}^{-1}\right)\end{array}$ & $\begin{array}{c}\text { Power } \\
\text { density } \\
\left(\mathrm{Jg}^{-1} \mathrm{~s}^{-1}\right)\end{array}$ \\
\hline A- H90H50 & 1.5 & $8.9-89.3$ & $2.6-26.0$ & $44.7-448.4$ & $0.04-4.7$ \\
B-H90H60 & 1.5 & $11.9-119.0$ & $0.1-1.0$ & $59.8-597.0$ & $1.20-12.6$ \\
C-H90H70 & 1.5 & $8.9-89.3$ & $5.0-50.0$ & $44.7-448.4$ & $0.03-0.3$ \\
\hline
\end{tabular}

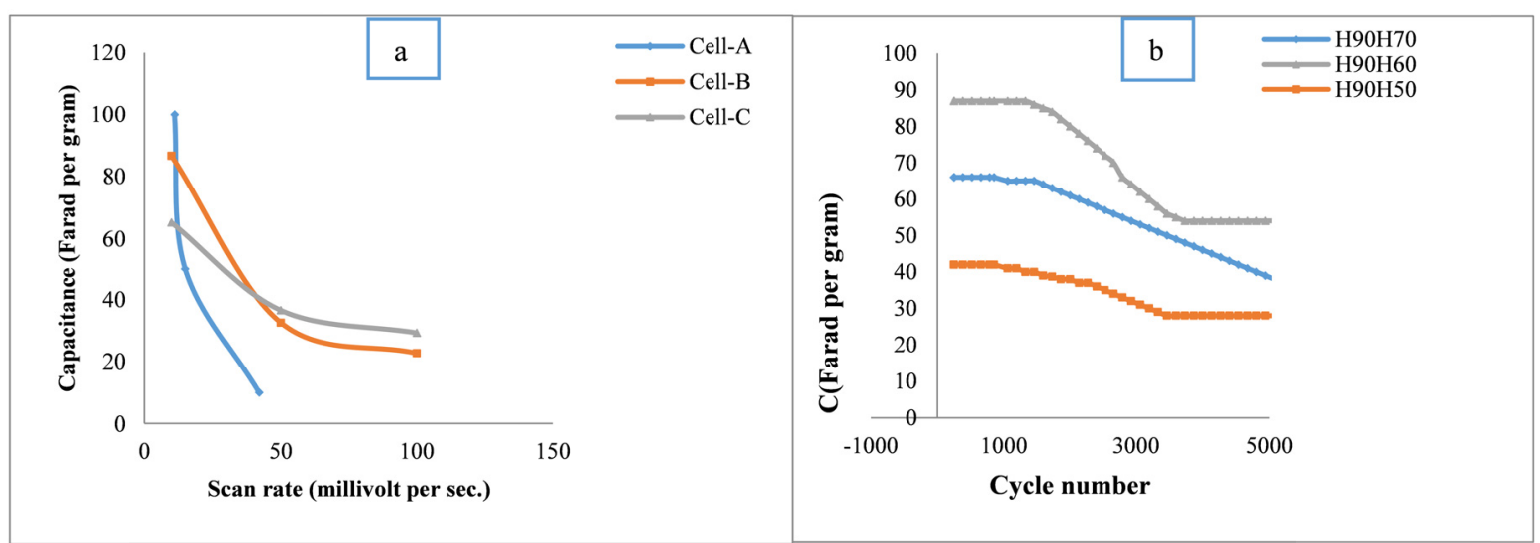

Figure 12. (a); combined graphs of capacitance against the scan rates for cells A, B and C. (b); combined cyclic performances of cells A, B and C 

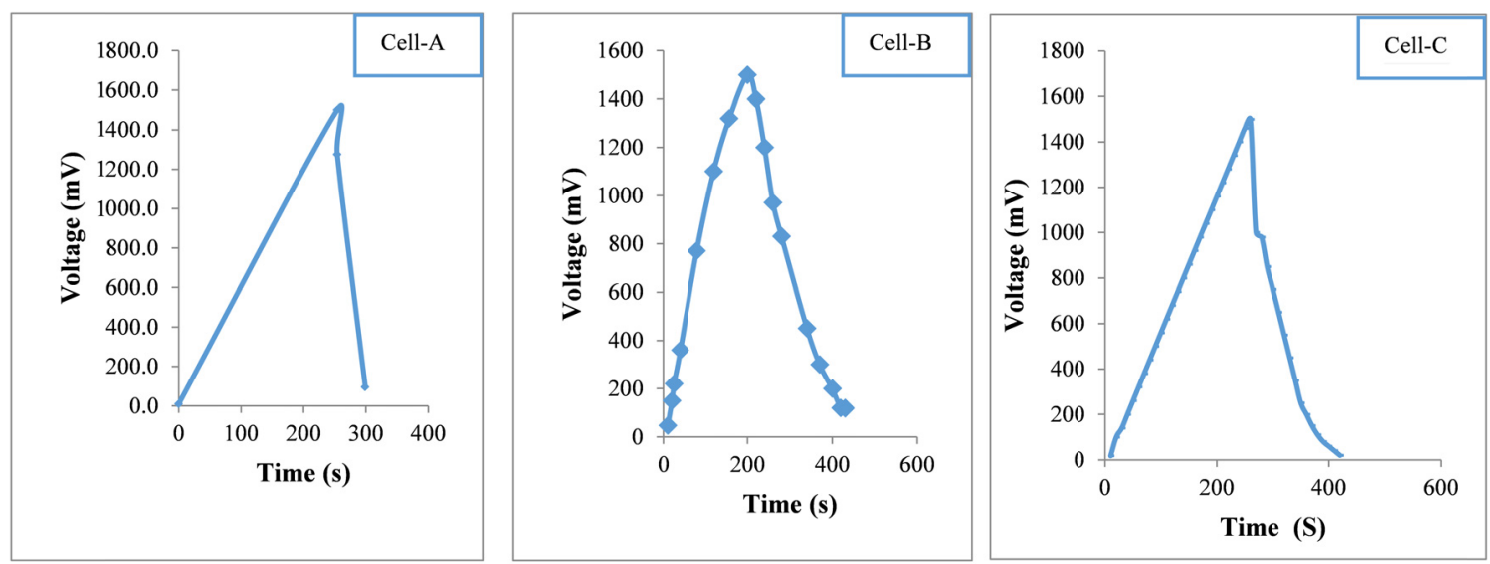

Figure 13. CD graphs of (a); cell- A (b); cell- B and (c); cell- C

The galvanostatic $\mathrm{CD}$ test is considered a better alternative and arguably quantitative method to evaluate the supercapacitive nature of an electrode material compared to the CV measurement (Shu et al., 2013), the capacitance of the cells was measured using this technique. The CD graphs of (a); Cell-A (b); Cell-B and (c); Cell- $\mathrm{C}$ were all depicted at a working voltage of $1.5 \mathrm{~V}$ and at three different current densities i.e. 10, 20 and $100 \mathrm{~mA}$ in Figure 13. The effective capacitance, power and energy densities were calculated and the following results were obtained. In cell-A, the discharged capacitances were calculated to be $8.90 \mathrm{Fg}^{-1}, 17.80 \mathrm{Fg}^{-1}$ and $89.28 \mathrm{Fg}^{-1}$ respectively at an applied current density of 100,20 and $10 \mathrm{~mA}$; the calculated energy and power densities are $44.70 \mathrm{Jg}^{-1} / 0.05 \mathrm{Jg}^{-1} \mathrm{~s}^{-1}, 89.41 \mathrm{Jg}^{-1} / 0.10 \mathrm{Jg}^{-1} \mathrm{~s}^{-1}$ and $448.40 \mathrm{Jg}^{-1} / 4.66 \mathrm{Jg}^{-1} \mathrm{~s}^{-1}$ respectively, for the same above mentioned current densities. While in cell-B, the discharged capacitances obtained were $11.9 \mathrm{Fg}^{-1}$, $23.8 \mathrm{Fg}^{-1}$ and $119.0 \mathrm{Fg}^{-1}$ respectively at an applied current density of 10, 20 and $100 \mathrm{~mA}$; the calculated energy and power densities are $59.8 \mathrm{Jg}^{-1} / 0.04 \mathrm{Jg}^{-1} \mathrm{~s}^{-1}, 119.5 \mathrm{Jg}^{-1} / 0.08 \mathrm{Jg}^{-1} \mathrm{~s}^{-1}$ and $597.0 \mathrm{Jg}^{-1} / 12.55 \mathrm{Jg}^{-1} \mathrm{~s}^{-1}$ at the said current densities. And finally cell-C has the following results for the capacitance; $8.89 \mathrm{Fg}^{-1}, 17.80 \mathrm{Fg}^{-1}$ and $89.28 \mathrm{Fg}^{-1}$ respectively at an applied current density of 10,20 and $100 \mathrm{~mA}$; power/energy densities are 44.70 $\mathrm{Jg}^{-1} / 0.02 \mathrm{Jg}^{-1} \mathrm{~s}^{-1}, 89.41 \mathrm{Jg}^{-1} / 0.05 \mathrm{Jg}^{-1} \mathrm{~s}^{-1}$ and $448.40 \mathrm{Jg}^{-1} / 0.25 \mathrm{Jg}^{-1} \mathrm{~s}^{-1}$ at the aforementioned current densities. The discharged capacitance decreases with the increase in current density was noticed in each of the resulting discharging capacitance of the cells, which could be as a result of the low penetration of ions into the inner region of the pores due to fast potential changes. Generally, the fade in capacitance could be as a result of dissolution of the active materials in the electrolytes, mechanical faults of the electrode (such as expansion, agglomeration) and imbalance of the two electrodes which can cause the instability of the electrode potential (Wang et al., 2013).

\section{Conclusion}

This research demonstrated the fabrication of a CPHWMCNTs used as an electrode for high performance supercapacitors using HPSE which function as an electrolyte and a separator. Three cells were successfully fabricated which were leveled as cell-A (H90PVdF-HFP10 |H50| H90PVdF-HFP10, cell-B (H90PVdF-HFP10 $|\mathrm{H} 60|$ H90PVdF-HFP10 and cell-C (H90PVdF-HFP10 |H70| H90PVdF-HFP10) with changes in the separator. The XRD analysis depicts the peaks of the sample electrode C90PVdF-HFP10 appearing at $\theta=26^{\circ}$ and $\theta=43^{\circ}$ which might be as a result of the hexagonal structure of (002) and (101) respectively, this also an indication that the carboxyl multiwalled CNT have high conductivity. Again, a wider diffraction at $\theta=20.1^{0}$ which correspond to crystalline peaks of PVDF. TGA traces shows that, the pure CPHMWCNTs experienced a major loss of just $10.0522 \%$, occurring at $696.58^{\circ} \mathrm{C}$ leaving a residue of $88.7270 \%$, which also prove that pure MWCNT have very good thermal stability and consequently, good, in application for electrochemical devices. From the overall of the electrochemical analysis of CV results, cell-B delivered higher capacitance of $86.6 \mathrm{Fg}^{-1}$ which doubles the capacitance obtained by cell-A $\left(42.1 \mathrm{Fg}^{-1}\right)$. In $\mathrm{CD}$ analysis with much lower voltage window of $1.5 \mathrm{~V}$, cell-B delivered better capacitance than cells $\mathrm{A}$ and $\mathrm{C}$, delivering a balanced and a better discharge capacitance of $119.0 \mathrm{Fg}^{-1}$ with higher energy/power densities of $597.0 \mathrm{Jg}^{-1} / 12.6 \mathrm{Jg}^{-1} \mathrm{~s}^{-1}$ and lowest in terms of internal resistance.

\section{Acknowledgements}

Our sincere gratitude and appreciations goes to the management of the Faculty of Science and Technology USIM under which ERGS grant (USIM/ERGS-FST-52-50111) has been provided for the purpose of this research. 


\section{Reference}

Böckenfeld, N., Jeong, S. S., Winter, M., Passerini, S., \& Balducci, A. (2013). Natural, Cheap and Environmentally Friendly Binder for Supercapacitors. Journal of Power Sources, 221, 14-20. http://dx.doi.org/ 10.1016/j.jpowsour.2012.07.076

Burke, A. (2009). Capacitors Application. Encyclopedia of Electrochemical Power Sources, l, 685-694. $\mathrm{http} / / \mathrm{dx}$.doi.org/10.1016/B978-044452745-5.00357-9

Capek, I. (2009). Dispersions, Novel Nanomaterial Sensors and Nanoconjugates Based on Carbon Nanotubes". Advances in Colloid and Interface Science, 150, 63-89. http//dx.doi.org/ 10.1016/j.cis.2009.05.006

Dong, B., He, B., Xu, C., \& Li, H. (2007). Preparation And Electrochemical Characterization Of Polyaniline/Multi-Walled Carbon Nanotubes Composites For Supercapacitor. Material Sci. and Engineering, 143, 7-13. http//dx.doi.org/ 10.1016/j.mseb.2007.06.017

Dubal, D. P., Gund, G. S., Lokhande, Holze, R., \& Chandrakant, D. L. (2013). Mild Chemical Strategy to Grow Micro-Roses and Micro-Woolen like Arranged $\mathrm{CuO}$ Nanosheets for High Performance Supercapacitors. Journal of Power Sources, 242, 687-698. http://dx.doi.org/ 10.1016/j.jpowsour.2013.05.013

Dubal, D.P., Gund, G. S., Lokhande, Holze, R., \& Chandrakant, D. L. (2014). Enhancement in Supercapacitive Properties of $\mathrm{CuO}$ Thin Films due to the Surfactant Mediated Morphological Modulation. Journal of Electroanalytical Chemistry, 712, 40-46. http://dx.doi.org/ 10.1016/j.jelechem.2013.10.025

Gund, G. S., Dubal, D.P., Patil, B.H., Shinde, S. S., \& Chandrakant, D. L. (2013). Enhanced Activity of Chemically Synthesized Hybrid Graphene oxide/Mn3O4 Composite for High Performance Supercapacitors. Electrochimica Acta, 92, 205-215.

Hashim, M. A, Sa'adu, L., \& Dasuki, A. K. (2012). Supercapacitor Based On Activated Carbon And Polymer Electrolyte. International Journal Of Sustainable Energy And Environmental Research, 1, 1-6.

Hashim, M. A, Sa'adu, L., Baharuddin, M. \& Dasuki, A. K. (2014). Using PVA, Methacrylate and Lauroyl Chitosan as Separator in Supercapacitors. Journal of Materials Science Research, 3, 1. http://dx.doi.org/ 10.5539/jmsr.v3n1p25

Hashim, M. A., \& Khiar, A. S. A (2011). Supercapacitor Based On Activated Carbon and Hybrid Polymer Electrolyte. Material Research Innovations, 15, s63-s66

Inagaki, M., Kang, F., Toyoda, M., \& Konno, H. (2014). Chapter 1 - Introduction. In M. Inagaki, F. Kang, M. Toyoda, H. Konno, \& B. Butterworth-Heinemann (Comp. \& Eds.), Advanced Materials Science and Engineering of Carbon (pp. 1-13). http//dx.doi.org/ 10.1016/B978-0-12-407789-8.00001-6

Inagaki, M., Kang, F., Toyoda M., \& H. Konno. (2014). Chapter 15 - Carbon Materials for Adsorption of Molecules and Ions. In M. Inagaki, F. Kang, M. Toyoda, \& H. Konno, B. Butterworth-Heinemann (Comp. \& Eds.), Advanced Materials Science and Engineering of Carbon (pp. 335-361). http//dx.doi.org/10.1016/B978 -0-12-407789-8.00015-6

Jiang, L., Vangari, M., Pryor, T., Xiao, Z., \& Korivi, N. S. (2013). Miniature Supercapacitors Based on Nanocomposite Thin Films. Microelectronic Engineering, 111, 52-57. http//dx.doi.org/10.1016/j.mee.2013. 01.030

Kim, J. K., Niedzicki, L., Scheers, J., Shin, C. R., Lim, D. H., Wieczorek, W., ...Per, J. (2013). Characterization Of N-Butyl-N-Methyl-Pyrrolidinium Bis(Trifluoromethanesulfonyl)Imide-Based Polymer Electrolytes For High Safety Lithium Batteries. Journal of Power Sources, 224, 93-98. http://dx.doi.org/10.1016/j.jpowsour. 2012.09.029

Li, Q., Li, Z., Lin, L., Wang, X.Y., Wang, Y., Zhang, C., \& Wang, H. (2010). Facile Synthesis of Activated Carbon/Carbon Nanotubes Compound For Supercapacitor Application. Chemical Engineering Journal, 156, 500-504. http//dx.doi.org/ 10.1016/j.cej.2009.10.025

Lim, D. H., Manuel, J., Ahn, J. H., Kim, J. K., Jacobsson, P., Matic, A., ...Kim, K. W. (2012). Polymer Electrolytes Based on Poly(Vinylidene Fluoride-Co-Hexafluoropropylene) Nanofibrous Membranes Containing Polymer Plasticizers for Lithium Batteries Solid State Ionics, 225, 631-635. http://dx.doi.org/ 10.1016/j.ssi.2012.03.028

Perera, S. D., Liyanage, A. D., Nijem, N., Ferraris, J. P., Chabal, Y. J., Kenneth, J., \& Balkus, J. (2013). Vanadium Oxide Nanowire - Graphene Binder Free Nanocomposite Paper Electrodes for Supercapacitors: A facile 
Green Approach. Journal of Power Sources, 230, 130-137. http://dx.doi.org/10.1016/j.jpowsour. 2012.11.118

Qian, H., Diao, H., Shirshova, N., Greenhalgh, E.S., Steinke, J. G. H., Shaffer, M. S. P., \& Alexander, B. (2013). Activation of Structural Carbon Fibres for Potential Applications in Multifunctional Structural Supercapacitors. Journal of Colloid and Interface Science, 395, 241-248. http://dx.doi.org/10.1016/j.jcis. 2012.12.015

Shi, S., Xu, C., Yang, C., Li, J., Du, H., Li, B., \& Feiyu, K. (2013). Flexible Supercapacitors. Particuology, 11, 371-377. http//dx.doi.org/10.1016/S0378-7753(01)00938-7

Shu, D., Lv, C., Cheng, F., He, C., Yang, K., Nan, J., \& Long, L. (2013). Enhanced Capacitance and Rate Capability of Nanocrystalline VN as Electrode Materials for Supercapacitors . Int. J. Electrochem. Sci., 8, $1209-1225$.

Snook, G. A., Kao, P., \& Adam, S. (2011). Best, Conducting-Polymer-Based Supercapacitor Devices and Electrodes. Journal of Power Sources, 196, 1-12. http//dx.doi.org/ 10.1016/j.jpowsour.2010.06.084

Stolarska, M., Niedzicki, L., Borkowska, R., Zalewska, A., \& Wieczorek, W. (2007). Structure, transport properties and interfacial stability of $\mathrm{PVdF} / \mathrm{HFP}$ electrolytes containing modified inorganic filler. Electrochimica Acta, 53, 1512-1517.

Van Hooijdonk, E., Bittencourt, C., Snyders, R., \& Colomer, J. F. (2013). Functionalization of vertically aligned carbon nanotubes. Beilstein J Nanotechnol, 4, 129-52.

Wang, A., Yang, Y., Huang, Z., \& Kang, F. (2013). A high-performance asymmetric supercapacitor based on carbon and carbon-MnO2 nanofiber electrodes. Carbon, 61, 190-199.http://dx.doi.org/10.1016/j.carbon. 2013.04.084.

Wu, T.-H., Chu, Y.-H., Hu, C.-C., \& Laurence, J. H. (2013). Criteria Appointing the Highest Acceptable Cell Voltage of Asymmetric Supercapacitors. Electrochemistry Communications, 27, 81-84.

Wu, T.-H., Chu, Y.-H., Hu, C.-C., \& Laurence, J. H. (2013). Criteria Appointing the Highest AccepTable Cell Voltage of Asymmetric Supercapacitors. Electrochemistry Communications, 27, 81-84. http://dx.doi.org/ 10.1016/j.elecom.2012.10.033

Zhao, T., Jiang, H., \& Ma, J. (2011). Surfactant-Assisted Electrochemical Deposition of -Cobalt Hydroxide For Supercapacitors. Journal of Power Sources, 96, 860-864. http://dx.doi.org/ 10.1016/j.jpowsour.2010.06.042

\section{Copyrights}

Copyright for this article is retained by the author(s), with first publication rights granted to the journal.

This is an open-access article distributed under the terms and conditions of the Creative Commons Attribution license (http://creativecommons.org/licenses/by/3.0/). 